\title{
Aktivitas Komite Audit, Kepemilikan Institusional dan Biaya Audit
}

\author{
Linda Kusumaning Wedari \\ Fakultas Ekonomi dan Bisnis, Universitas Katholik Atma Jaya \\ Jl. Jenderal Sudirman 51, Jakarta 12930 \\ Email: lindakusumaningwedari@yahoo.com
}

\begin{abstract}
ABSTRAK
Penelitian ini meneliti pengaruh aktivitas komite audit dan kepemilikan institusional terhadap biaya audit perusahaan publik di Indonesia. Perusahaan yang digunakan sebagai sampel adalah perusahaan manufaktur yang terdaftar di Bursa Efek Indonesia selama periode 2010-2013. Terdapat 124 pengamatan yang memenuhi kriteria sampel, data dianalisis menggunakan bantuan Eviews 6.0. Hasil penelitian menunjukkan bahwa aktivitas komite audit yang diukur dengan jumlah pertemuan komite audit, berpengaruh positif terhadap biaya audit. Sementara itu, variabel kepemilikan institusional, tidak berpengaruh terhadap biaya audit. Demikian pula, tidak ada perbedaan yang signifikan antara kepemilikan institusional tersebar (diffused) dan kepemilikan institusional terkonsentrasi (blockholder) terhadap biaya audit. Hasil pengujian juga menunjukkan bahwa variabel kontrol jumlah anak perusahaan yang sepenuhnya dimiliki, anak perusahaan di luar negeri, dan kualitas audit berpengaruh secara signifikan terhadap biaya audit. Variabel kontrol lainnya, yaitu leverage, kerugian dan opini audit tidak berpengaruh terhadap biaya audit.
\end{abstract}

Kata kunci: Biaya audit, kegiatan komite audit, kepemilikan institusional diffused dan blockholders.

\begin{abstract}
This study investigates the influence of the audit committee activities and institutional ownership to the audit fees in Indonesia public companies. The research samples are manufacturing companies listed in Indonesia Stock Exchange for the period 2010 - 2013. There are 124 observations that meet the sample criteria, data are analyzed using Eviews 6.0. The results show that the audit committee activities which measured by the number of audit committee meetings have significant positive effect on the audit fees. Meanwhile, institutional ownership, diffused and blockholders institutional ownership do not significantly affect to the audit fees. However some of the control variables such as the number of wholly-owned subsidiaries, subsidiaries abroad, and audit quality have significant positive effect on audit fees, whereas leverage, loss and audit opinion have no significant effect on the audit fee.
\end{abstract}

Keywords: Audit fees, audit committee activities, ownerships institutional diffused and blockholders.

\section{PENDAHULUAN}

Perhatian ke masalah corporate governance mengalami peningkatan pesat sejak beberapa kasus kegagalan perusahaan listing di BEI. Komite audit dan kepemilikan saham dianggap menjadi alternatif yang dipilih untuk mengatasi masalah corporate governance dan akuntabilitas perusahaan yang lebih tinggi (Verschoor, 1993).
Panel (2004) dan Abbott and Parker (2000) menyatakan bahwa audit komite merupakan elemen penting dalam corporate governance dan dalam menjamin kualitas pelaporan keuangan. Telah ada berbagai penelitian mengenai pengaruh barbagai faktor corporate governance atas pelaporan keuangan dan kualitas audit dan tingkat biaya audit (Gul and Tsui 2001, Carcello et al, 2002; Abbott et al, 2003; Tsui et al, 2001). Berbagai penelitian ini 
dilakukan karena adanya pemisahan kepemilikan dan pengendalian sehingga terdapat masalah keagenan (agency problems) atas kualitas angkaangka akuntansi yang dilaporkan. Konflik keagenan muncul saat pihak manajemen terpisah dari pemilik. Pihak manajemen bertindak atas kepentingan pribadi dan memberikan hasil laporan keuangan yang keliru dengan alasan 'oportunistis' meski hal itu berarti merugikan kepentingan para pemegang saham (Jensen and Meckling, 1976). Peranan kualitas audit yang tinggi sangat penting untuk memeriksa dan membatasi perilaku manajerial oportunistik (Becker et al, 1998)

Pemegang saham dengan tingkat kepemilikan saham yang besar, baik oleh perorangan, maupun institusional, akan secara aktif memonitor manajemen perusahaan dan membatasi fleksibilitas akuntansi untuk menghasilkan laporan keuangan yang menyimpang untuk kepentingan pribadi. Pada situasi ini, dampak negatif dari masalah keagenen (agency problem) dan risiko bawaan (inherent risk) dari salah saji material dalam pelaporan keuangan akan berkurang. Pada klien tersebut, auditor akan menetapkan risiko audit lebih rendah sehingga aktivitas audit juga lebih rendah yang pada akhirnya memberikan biaya audit lebih rendah. Selain itu, dengan tingkat kepemilikan oleh manajemen yang tinggi mendorong manajer menghasilkan informasi yang lebih relevan dibandingkan hanya menyusun angka akuntansi secara oportunis demi kepentingan pribadi. Hal ini mengakibatkan hilangnya risiko inheren dari salah saji material sehingga mengurangi risiko audit dan biaya audit. Permintaan untuk jasa audit dan audit yang berkualitas merupakan usaha yang efisien untuk contracting problem (Watts and Zimmerman, 1986).

Penelitian ini akan melakukan analisis berdasarkan argumen monitoring dari pemegang saham dan mengusulkan bahwa pemegang saham besar secara aktif mengawasi dan berpengaruh terhadap pilihan metode akuntansi dan strategi untuk menghasilkan informasi keuangan. Dalam mengembangkan argumen, peneliti mempertimbangkan pengaruh, baik faktor supply maupun faktor demand karena keduanya memungkinkan terjadinya hubungan yang bertentangan antara karakteristik kepemilikan dengan biaya audit. Faktor supply terkait dengan permintaan akan audit yang berkualitas tinggi yang diminta oleh pemegang saham sedangkan faktor demand terkait dengan dimintanya audit berkualitas tinggi karena manajemen ingin memberikan sinyal positif atas hasil kinerjanya.

Peneliti berpendapat bahwa hubungan antara struktur kepemilikan dan biaya audit juga ada dari sudut pandang demand-side. Dari satu sisi, pemegang saham yang kompleks akan meminta manajer perusahaan untuk menggunakan jasa audit berkualitas tinggi sebagai jaminan deteksi kecurangan laporan keuangan yang ada. Di sisi lain, manajer dapat membeli jasa audit berkualitas tinggi dan luas untuk meningkatkan kredibilitas informasi laporan keuangan untuk menarik minat investor dan pemegang saham besar. Selain itu, manajer ingin menciptakan persepsi (penilaian) positif untuk memperoleh berbagai manfaat ekonomi. Oleh karena itu, biaya audit ditentukan baik oleh faktor demand maupun supply.

Komite audit bukan bersifat wajib (mandatory) dan tidak selalu ada pada perusahaan kecil, namun komite audit wajib ada pada perusahaan publik sesuai aturan BAPEPAM. Peran komite audit dalam corporate governance makin penting. Dalam peraturan Bapepam IX.1.5 tahun 2012 menekankan pada peran komite audit dalam pengawasan pada proses pelaporan keuangan dan mengawasi hubungan antara manajemen perusahaan dan auditor eksternal. Pada peraturan Bapepam tersebut telah menyebutkan mengenai komposisi dan aktivitas komite audit. Tanggung jawab komite audit meliputi: mengawasi laporan keuangan, mengawasi audit eksternal, dan mengamati sistem pengendalian internal (termasuk audit internal). Dari ketiga tanggung jawab tersebut, pengawasan pada laporan keuangan dan pengawasan pada audit eksternal adalah yang berkaitan dengan biaya audit. Pengawasan pada laporan keuangan meliputi review laporan keuangan dan kebijakan akuntansi. Komite Audit merupakan sub-komite dewan direksi utama dari perusahaan, biasanya terbentuk dari direktur noneksekutif dan bertanggung jawab pada hal-hal yang berkaitan dengan pelaporan keuangan dan audit (Spira LF, 1999).

Penelitian ini mengacu pada penelitian Santanu, Hossain and Deis (2007) mengenai hubungan empiris antara karakteristik kepemilikan dan biaya audit. Namun dalam penelitian Santanu, variabel komite audit digunakan sebagai variabel kontrol yang diukur dengan dummy (ada atau tidak). Pada penelitian ini peneliti akan menggunakan variabel komite audit sebagai variabel independen yang diukur dengan jumlah rapat komite audit yang telah dilakukan oleh perusahaan sampel. Peneliti berargumen bahwa jumlah rapat dapat sebagai indikator terhadap tingkat pengawasan dan tingkat efektivitas dari komite audit sebagai salah satu elemen pelaksanaan Good Corporate Governance (GCG). Penelitian ini bertujuan untuk menganalisis pengaruh aktivitas komite audit terhadap biaya audit dan menganalisis perbedaan pengaruh kepemilikan 
institusional blockholder dan kepemilikan institusional diffused terhadap biaya audit.

Berdasarkan penjelasan di atas maka menarik untuk dilakukan penelitian pengaruh aktivitas komite audit dan kepemilikan institusional terhadap biaya audit.Penelitian ini juga akan menggunakan beberapa variabel kontrol yaitu jumlah anak perusahaan (SUB) dan FOREIGN sebagai proxy dari auditee complexity (Carcello et al.,2002; Mitra, 2007), Leverage sebagai proxy dari resiko keuangan (Abbott et al (2003), LOSS sebagai proxy dari profitabilitas (Sharma et al,2009; Adelopo,2012), Opinion dan Quality (audit quality) (Palmrose (1986), Barkess\&Simnett (1994)) sebagai tambahan variabel kontrol yang diperkirakan akan ikut mempengaruhi biaya audit.

\section{Teori Keagenan (Agency Theory)}

Jensen dan Meckling (1976) dan Scott (1997) menggambarkan hubungan keagenan (agency relationship) sebagai hubungan yang timbul karena adanya kontrak yang ditetapkan antara principal yang menggunakan agen untuk melakukan jasa yang menjadi kepentingan principal dalam hal terjadi pemisahan kepemilikan dan kontrol perusahaan. Secara garis besar, Jensen dan Meckling (1976) menggambarkan dua macam bentuk hubungan keagenan, yaitu antara manajer dan pemegang saham, serta hubungan antara manajer dan pemberi pinjaman (bondholders). Agar hubungan kontraktual ini dapat berjalan lancar, principal akan mendelegasikan otoritas pembuatan keputusan kepada agen dan hubungan ini juga perlu diatur dalam suatu kontrak yang biasanya menggunakan angka-angka akuntansi yang dinyatakan dalam laporan keuangan sebagai dasarnya. Pendesainan kontrak yang tepat untuk menyelaraskan kepentingan agen dan principal dalam hal terjadi konflik kepentingan inilah

Masalah keagenan (agency problem) sebenarnya muncul ketika principal kesulitan untuk memastikan bahwa agen bertindak untuk memaksimumkan kesejahteraan principal. Sebagai contoh, agen dalam hal ini manajer memiliki insentif untuk meningkatkan kesejahteraannya sendiri dengan menggunakan fasilitas yang dipercayakan oleh pemegang saham atau dana yang diperoleh dari pemberi pinjaman (bondholders). Upaya untuk mengatasi atau mengurangi masalah keagenan ini akan menimbulkan biaya keagenan (agency cost) yang akan ditanggung baik oleh principal maupun agen. Jensen dan Mecling (1976) membagi biaya keagenan ini menjadi biaya pengawasan (monitoring cost), biaya kewajiban (bonding cost), dan kerugian residu (residual loss).
Monitoring cost adalah biaya yang timbul dan ditanggung oleh principal untuk memonitor perilaku agen, yaitu untuk mengukur, mengamati, dan mengontrol perilaku agen. Contoh biaya ini adalah biaya audit dan biaya untuk menetapkan rencana kompensasi manajer, pembatasan anggaran, dan aturan-aturan operasi. Sementara bonding cost merupakan biaya yang ditanggung oleh agen untuk menetapkan dan mematuhi mekanisme yang menjamin bahwa agen akan bertindak untuk kepentingan principal. Misalnya, biaya yang dikeluarkan oleh manajer untuk menyediakan laporan keuangan kepada pemegang saham. Pemegang saham hanya akan mengijinkan biaya kewajiban (bonding cost) terjadi jika biaya tersebut dapat mengurangi biaya pengawasan. Sedangkan kerugian residu timbul dari kenyataan bahwa tindakan agen kadangkala berbeda dari tindakan yang memaksimumkan kepentingan principal.

\section{Komite Audit}

Komite adalah sekelompok orang yang dipilih oleh kelompok yang lebih besar, untuk mengerjakan pekerjaan tertentu atau untuk melakukan tugas-tugas khusus. Di dalam perusahaan, komite sangat berguna untuk menangani masalah-masalah yang membutuhkan integrasi dan koordinasi sehingga dimungkinkan permasalahan-permasalahan yang signifikan atau penting dapat segera teratasi (Tugiman 1995). Manfaat komite audit yang dibentuk sebagai sebuah komite khusus di perusahaan untuk mengoptimalkan fungsi pengawasan yang sebelumnya merupakan tanggung jawab penuh dari dewan komisaris. Hubungan yang erat antara komite audit dan dewan komisaris ini juga nampak dalam kewajiban pelaporan komite audit. Komite audit bertanggung jawab kepada dewan komisaris atas pelaksanaan tugas yang telah ditentukan dan wajib membuat laporan kepada dewan komisaris atas setiap penggunaan yang diberikan (BAPEPAM 2004).

Pedoman yang digunakan oleh penelitian ini mengenai apa yang seharusnya dilakukan oleh komite audit adalah dari SAS No. 61 "Communications with Audit Committee," dan SAS No. 90 "Audit Committee Communications." Komite audit mendorong terjadinya interaksi antara manajemen dengan auditor eksternal, termasuk mengenai estimasi akuntansi, penilaian (judgement) dari manajemen, dan ketidaksepakatan antara manajemen dan auditor eksternal. Komite audit juga dapat mengevaluasi masalah hukum dan peraturan pemerintah yang dapat mempengaruhi resiko perusahaan dan laporan keuangan perusahaan. 
Peran Komite Audit dalam Proses Negosiasi Audit

Menurut Abbott et.al (2003a) komite audit dapat melakukan tiga tindakan berukut berkaitan dengan auditor eksternal dalam rangka menghasilkan lingkup audit atau audit assurance yang lebih tinggi.

1. Anggota komite dapat meminta manajemen untuk memilih auditor yang terkenal dengan reputasi tinggi. Abbott \& Parker (2000) menemukan bahwa perusahaan dengan komite audit yang semuanya anggota berasal dari dewan komisaris independen, yang bertemu (mengadakan rapat) minimal dua (2) kali dalam setahun cenderung memilih auditor dari KAP Big 5.

2. Komite audit dapat meminta lingkup audit yang lebih luas kepada auditor eksternal (Simunic \& Stein, 1996). Komite audit akan bertemu dengan ketua auditor independen perusahaan dan manajemen untuk mereview lingkup audit yang diusulkan pada tahun berjalan, prosedur audit yang akan ditempuh dan pada tahap akhir audit, mereview temuan audit termasuk komentar dan rekomendasi dari ketua tim auditor independen. Bila memperluas lingkup audit dikaitkan dengan meningkatnya kualitas, maka juga dapat dikatakan kualitas komite audit juga meningkat. DeZoort (1997) menemukan bukti mengenai keterlibatan komite audit dengan tugas audit eksternal, bahwa tugas utama anggota komite audit adalah untuk mereview hasil pekerjaan auditor eksternal.

3. Komite audit secara tidak langsung dapat mempengaruhi luasnya lingkup audit dengan mengurangi ancaman manajemen untuk mengganti auditor (Knapp 1985). Demikian pula, pada saat penentuan lingkup audit (pada tahap perencanaan audit) sering melibatkan negosiasi antara auditor dan manajemen, dan manajemen memiliki keinginan untuk meminimalkan biaya audit (Knapp 1985; Emby dan Davidson 1998). Dengan adanya negosiasi ini, komite audit dapat melindungi auditor dari tekanan manajemen untuk menyelesaikan audit dengan cepat, menerima representasi manajemen tanpa bukti yang memadai atau ruang lingkup audit yang terbatas, sehingga mengurangi kewenangan auditor.

\section{Aktivitas Komite Audit}

Komite audit harus memiliki saluran komunikasi langsung dengan auditor eksternal untuk membahas dan mengkaji isu-isu spesifik yang sesuai. Pertemuan rutin antara komite audit dan auditor eksternal membuatnya komite audit akan tetap memiliki informasi dan pengetahuan tentang isu-isu akuntansi dan audit yang relevan (Raghunandan et al. 2001). Menon dan Williams (1994) menyatakan bahwa frekuensi rapat adalah sinyal mengenai ketekunan komite audit. Dari peraturan Bapepam, menunjukkan bahwa: (1) frekuensi pertemuan merupakan komponen penting dari aktivitas komite audit, dan (2) frekuensi pertemuan sering digunakan sebagai proksi untuk ketekunan komite audit. Agar komite audit menjadi efektif, maka diperlukan waktu dalam melaksanakan tugasnya.

Penelitian terbaru mendukung pentingnya frekuensi pertemuan komite audit. Beasley et al. (2000) menemukan bahwa komite audit dari perusahaan yang melakukan penipuan (fraud), bertemu kurang sering daripada komite audit dari perusahaan non-fraud. Abbott et al. (2003a) menemukan bahwa perusahaan dimana komite audit melakukan pertemuan setidaknya empat kali setiap tahun cenderung tidak menyajikan kembali laporan keuangan auditan. Komite audit yang sering mengadakan pertemuan, lebih memiliki informasi tentang masalah audit saat ini dan lebih rajin dalam melaksanakan tugas-tugas mereka. Hal ini berarti bahwa komite audit yang sering bertemu secara proaktif dan positif dapat mempengaruhi cakupan audit selama tahapan audit. Komite audit yang efektif dapat dilihat oleh auditor sebagai meningkatkan lingkungan kontrol keseluruhan, sehingga mengurangi risiko pengendalian auditor dan jumlah yang dihasilkan dari pekerjaan audit dianggap perlu (Tsui et al. 2001).

\section{Kepemilikan Saham dan Biaya audit}

Menurut Bursa Efek Indonesia, saham (stock) merupakan salah satu instrumen pasar keuangan yang paling popular. Menerbitkan saham merupakan salah satu pilihan perusahaan ketika memutuskan untuk pendanaan perusahaan. Pada sisi yang lain, saham merupakan instrumen investasi yang banyak dipilih para investor karena saham mampu memberikan tingkat keuntungan yang menarik.

Monks, Robert AG \& Minow (2011) menyatakan bahwa kepemilikan saham berkaitan dengan hak suara dalam suatu perusahaan sesuai dengan proporsi kepemilikannya. Struktur kepemilikan menggambarkan para pihak pemegang saham dan porsi kepemilikan yang dimiliki oleh investor dalam perusahaan, yang berkaitan dengan pengaruhnya di dalam perusahaan.

Dalam struktur kepemilikan perusahaan, investor dapat berupa investor individual atau 
perseorangan dan investor institusional. Kepemilikan Instutisional dipengaruhi oleh jumlah saham yang dimiliki oleh pihak institusi dari keseluruhan saham yang beredar. Institusi yang dimaksud berupa perusahaan asuransi, perusahaan swasta atau pemerintah, bank, mutual funds, yayasan, atau bentuk institusi lainnya (Monks, Robert AG \& Minow (2011).

Tingkat kepemilikan saham instritusional yang besar akan mempengaruhi aktivitas pengawasan yang dilakukan oleh para pemegang saham atas tindakan yang dilakukan oleh perusahaan termasuk pada proses pelaporan keuangan. Berdasarkan penelitian dari Carcello et al. 2002; Abbott et al. 2003b) memberikan bukti yang sesuai dengan demand-side perspective bahwa mekanisme tata kelola (governance) mensyaratkan digunakannya jasa audit yang berkualitas tinggi untuk mengurangi agency costs dan mengurangi kecenderungan adanya kecurangan dalam pelaporan keuangan, yang mengakibatkan semakin tingginya biaya audit. Penelitian lain dari Gul and Tsui (1998) dan Tsui et al (2001), memberikan bukti terkait dengan supply-side (risk-based) perspective bahwa faktor tata kelola (governance) dapat mengurangi masalah keagenan dalam pelaporan keuangan dan mengurangi resiko salah saji akuntansi, sehingga lingkup pekerjaan audit menjadi lebih sempit yang pada akhirnya akan menurunkan biaya audit.

Kane and Velury (2004) menemukan bahwa semakin tinggi tingkat kepemilikan institutional maka cenderung akan makin mendorong perusahaan emiten membeli jasa audit dari kantor akuntan publik besar untuk mendapatkan hasil audit yang berkualitas. Hal ini akan meningkatkan nilai perusahaan, yaitu dengan meningkatkan peringkat kreditnya, mengurangi biaya utang (the cost of debt) dan biaya modal secara keseluruhan (cost of capital), menarik investasi institusional dan pada akhirnya akan meningkatkan kredibilitas perusahaan di pasar saham. Dengan demikian, tercipta hubungan positif antara kepemilikan dengan biaya audit.

\section{Pengembangan Hipotesis}

\section{Pengaruh Karakteristik Komite Audit Ter- hadap Biaya Audit}

Hasil pekerjaan komite audit dapat meningkatkan reputasi direksi, tetapi juga dapat memperburuk reputasi karena terjadinya salah saji di laporan keuangan. Ketika komite audit menemukan salah saji yang material di laporan keuangan maka akan menurunkan reputasi direksi, sebaliknya ketika komite audit menyata- kan bahwa laporan keuangan tidak mengandung salah saji material maka akan meningkatkan reputasi dari direksi.

Pertemuan yang teratur antara komite audit dan auditor eksternal cenderung membuat komite audit tetap meng-up-to-date informasi mengenai audit dan akuntansi. Terdapat rekomendasi dari NACD (national association of corporate director) (Abbott et al. 2003) menyebutkan bahwa: (1) frekuensi pertemuan merupakan komponen penting dari efektivitas komite audit, (2) frekuensi pertemuan sering digunakan sebagai proxy kerajinan dari komite audit. Beasley et al (2000) menyebutkan komite audit dari perusahaan yang melakukan kecurangan bertemu kurang sering daripada komite audit dari perusahaan yang nonfraud (tidak melakukan kecurangan). Abbott et al (2000) menemukan bahwa perusahaan dengan komite audit yang bertemu minimal 4 kali dalam setahun cenderung tidak menyajikan ulang laporan keuangan auditan. Berdasarkan surat keputusan Ketua Bapepam dan LK Nomor: Kep643/BL/2012, Komite Audit mengadakan rapat secara berkala paling kurang satu kali dalam 3 (tiga) bulan. Pembentukan Dan Pedoman Pelaksanaan Kerja. Sedangkan berdasarkan peraturan ketua Bapepam nomor: KEP-29/PM/2004 yang menyatakan bahwa komite audit mengadakan rapat sekurang-kurangnya sama dengan ketentuan minimal rapat dewan komisaris yang ditetapkan dalam anggaran dasar, yaitu sekali dalam sebulan (Kharis dan Suhardjanto 2010). Semakin efektif komite audit maka semakin kecil kecenderungan untuk menyajikan kembali laporan keuangan yang berarti kemungkinan kecil laporan keuangan tersebut mengandung salah saji yang material. Hal ini dapat memberikan pengaruh menurunkan biaya audit.

Namun terdapat pendapat lain yang bertentangan bahwa ada pengaruh positif aktivitas komite audit terhadap biaya audit (Carcello et al. 2002; Adelopo et al. 2012). Hal ini terjadi karena komite audit berkepentingan untuk memberikan sinyal efisiensi, menjaga reputasi, dan menghindari resiko litigasi, sehingga memiliki konsekuensi, dimana makin sering komite audit bertemu atau mengadakan rapat maka mereka akan tetap menjaga keinginan dan mendesak manajemen untuk menjaga reputasi, dan menghindari resiko litigasi. Komite audit akan meminta manajemen untuk membeli jasa audit berkualitas tinggi sehingga sehingga akan meningkatkan biaya audit. Dari hasil yang bertentangan tersebut maka peneliti menetapkan hipotesis sebagai berikut: H1: Terdapat pengaruh jumlah pertemuan komite audit terhadap biaya audit. 
Pengaruh Kepemilikan Saham Institusional Diffused-Blockholder Terhadap Biaya Audit

Kane and velury (2004) berpendapat bahwa investor institusional berpengaruh terhadap manajemen dalam 2 (dua) cara. Pertama, sebagai penyedia modal yang besar, mereka berpengaruh terhadap perdagangan surat berharga sebesar persentase tertentu sehingga berdampak pada harga pasar dari saham. Mereka juga mempunyai pengaruh pada biaya modal perusahaan yang sangat penting bagi struktur modal perusahaan dan merupakan komponen dalam penilaian perusahaan. Kedua, karena kepemilikannya yang besar, investor institusional memiliki hak voting yang dapat digunakan untuk mempengaruhi keputusan stratejik manajemen.

Investor institusional biasanya memiliki informasi lebih baik daripada investor individual karena dapat informasi khusus yang berharga dan dianalisis tepat waktu. Untuk memenuhi tanggung jawab fiduciary, institusi mengembangkan suatu kebijakan investasi dan terus menerus memonitor portofolio. Peneliti berpendapat ketika pemegang saham institusional secara individual memiliki kurang dari $20 \%$ saham biasa beredar, dikatakan menyebar (diffused), tingkat pengawasan terhadap perusahaan emiten akan lebih rendah daripada pemegang saham institusional yang memiliki $20 \%$ atau lebih saham biasa beredar (blockholder). Ketika tingkat kepemilikan diffused pada investor institusional, pemegang saham cenderung kurang ada keinginan dan kemampuan untuk memonitor aktivitas perusahaan. Namun, apabila pemegang saham institusional meningkat, pemegang saham institusional blockholder menjadi lebih berpengaruh, memaksa perusahaan melakukan audit berkualitas tinggi untuk menghindari kecurangan dalam pelaporan keuangan.

Jensen dan Meckling (1976) menyebutkan bahwa aktivitas pengawasan pemegang saham besar akan lebih intensif ketika terkonsentrasi pada beberapa investor. Pengawasan aktif akan mengurangi resiko bawaan dan usaha audit yang direncanakan akan berkurang sehingga biaya auditpun berkurang. Blockholder cenderung berinvestasi pada perusahaan dengan review eksternal laporan keuangan berkualitas tinggi atau tidak pada perusahaan yang melakukan manipulasi agresif. Manajemen juga akan menggunakan jasa audit berkualitas tinggi untuk menarik investor besar.

Dari demand-side, tingkat investasi oleh pemegang saham institusional blockholder secara positif berpengaruh terhadap biaya audit. Dari supply-side, pemegang saham blockholder, secara aktif memonitor perusahaan termasuk proses pelaporan keuangan dan mengurangi risiko bawaan salah saji material, sehingga pada akhirnya akan meningkatkan biaya audit. Namun bagi pemegang saham kecil, pemegang saham institusional diffused tetap tidak tertarik dalam memonitor perusahaan termasuk keputusan stratejik manajer dan akan menjual saham yang mereka miliki apabila mereka kurang puas akan kinerja perusahaan. Dengan demikian, hipotesis yang diajukan adalah:

H2: Ceretis paribus, terdapat pengaruh kepemilikan institusional terhadap biaya audit.

H3: Ceretis paribus, terdapat beda pengaruh kepemilikan institusional diffused dan kepemilikan institusional blockholder terhadap biaya audit.

\section{METODE PENELITIAN}

\section{Populasi dan Sampel Penelitian}

Populasi penelitian ini meliputi semua perusahaan publik yang sahamnya terdaftar di Bursa Efek Indonesia (BEI). Sedangkan, sampel yang akan dipergunakan dalam penelitian ini dipilih berdasarkan kriteria-kriteria tertentu (purposive random sampling), yaitu perusahaan manufaktur yang menerbitkan laporan keuangan dengan periode yang berakhir 31 Desember selama periode pengamatan penelitian, tahun 2010 sampai 2013 (4 tahun); perusahaan yang mempunyai data kepemilikan saham, jumlah rapat komite audit dalam setahun dan jumlah biaya audit (karena mayoritas perusahaan tidak mencantumkan jumlah terinci biaya audit maka yang digunakan adalah professional fee). Pengambilan sampel dalam penelitian ini dilakukan dengan metode penggabungan data (pooling data).

\section{Jenis dan Sumber Data}

Data yang digunakan dalam penelitian ini merupakan data sekunder yang diperoleh dari laporan tahunan BEI di internet dengan situs www.idx.co.id dan publikasi lainnya yang terdiri data biaya audit (biaya professional), jumlah pertemuan komite audit, kepemilikan institusional, jumlah anak perusahaan, anak perusahaan di luar negeri, opini modified/unmodified, total assets, leverage dan nama KAP yang digunakan.

\section{Definisi Operasional Variabel}

Variabel terikat dalam penelitian ini adalah biaya audit sedangkan variabel bebasnya antara lain kepemilikan institusional, aktivitas komite audit. Selain itu, penelitian ini menggunakan 
variabel jumlah anak perusahaan, dummy anak perusahaan di luar negeri, dummy opini audit, leverage, dan ln total assets, sebagai variabel kontrolnya. Berikut disajikan definisi dari masingmasing variabel.

a. Variabel Terikat

Penelitian ini menggunakan biaya audit sebagai variabel terikatnya. Biaya audit diperoleh dari angka professional fees yaitu biaya yang dikeluarkan oleh perusahaan untuk jasa profesi. Setelah itu, angka professional fees di logaritma naturalkan.

b. Variabel Bebas

Variabel bebas yang digunakan dalam penelitian ini antara lain:

1. Jumlah pertemuan komite audit (KA_MEET) Jumlah pertemuan komite audit dalam penelitian ini diukur menggunakan jumlah rapat komite audit dalam satu tahun. Data ini diperoleh dari laporan tahunan yang dipublikasikan oleh perusahaan.

2. Kepemilikan institusional (INS_OWN) Kepemilikan institusional dalam penelitian ini menggunakan persentase saham yang dimiliki oleh insitusi. Institusi disini berupa perusahaan asuransi, investasi, bank, dan lembaga keuangan lainnya yang memang aktivitas utamanya melakukan investasi saham untuk memperoleh return.

3. Dummy Kepemilikan Institusional (D_INST) Dummy 0 adalah kepemilikan institusional diffused (menyebar) yang mana kepemilikan $<20 \%$. Sedangkan, dummy 1 adalah kepemilikan institusional blockholders yang mana kepemilikannya $\geq 20 \%$.

c. Variabel Kontrol

Sebagai tambahan atas variable independen, model juga akan memasukkan variable control untuk memoderasi karakteristik perusahaan dan pengaruh audit yang independen. Variabel kontrol yang digunakan dalam penelitian ini antara lain:

1. Anak perusahaan (SUB): akar dari jumlah anak perusahaan yang dimiliki (Gul et al, 2001; Carcello, 2002)

2. Adanya anak perusahaan luar negeri (FOREIGN): dummy 1 untuk yang memiliki anak perusahaan di luar negeri dan dummy 0 untuk yang tidak memiliki.

3. Opini audit (OPINI): dengan dummy 1 bagi perusahaan dengan unmodified opinion dan dummy 0 untuk yang mendapatkan modified opinion.

4. Rasio solvabilitas (LEV): diukur menggunakan rasio utang atau leverage Leverage $=$ long term debt $/$ total assets
5. Kerugian (LOSS): diukur dengan dummy 1 untuk perusahaan yang mengalami kerugian pada periode amatan dan dummy 0 untuk yang tidak mengalami kerugian.

6. Kualitas audit (QUALITY) = diukur menggunakan dummy, yang mana angka 1 menunjukkan perusahaan diaudit oleh kantor akuntan publik big four dan dummy 0 menunjukkan perusahaan diaudit oleh kantor akuntan publik non-big four. Kantor akuntan publik yang termasuk big four antara lain:

a) Pricewater house Coopers yang berafiliasi dengan Haryanto Sahari

b) Ernst \& Young yang berafiliasi dengan Purwantono, Sarwoko, Sandjaja

c) Deloitte Touche Tohmatsu yang berafiliasi dengan Osman Bing Satrio

d) KPMG yang berafiliasi dengan Sidharta, Sidharta, Widjaja.

\section{Metode Analisis Data}

Jenis software yang digunakan untuk melakukan regresi model ini adalah dengan Microsoft Excel dan Eviews 6.0. Analisis data yang dilakukan adalah analisis statistika deskriptif dan analisis regresi dengan data panel. Data panel merupakan penggabungan data time series dan cross section.

a. Analisis Statistika Deskriptif

Analisis statisktika deskriptif digunakan untuk memberikan gambaran atau deskripsi suatu data dalam penelitian, dalam hal ini meliputi seluruh variabel yang ada dalam penelitian ini (Ghozali 2011).

b. Analisis Data Panel

Berdasarkan Widarjono (2009) dalam analisa model data panel, terdapat tiga metode yang biasa digunakan untuk mengestimasi model regresi dengan E-Views, yaitu Pooled Ordinary Least Square atau Common Effect Method (CEM), Fixed Effect Method (FEM), dan Random Effect Method (REM). Teknik Pooled Ordinary Least Square atau CEM merupakan gabungan dari data cross-section dengan data time series (pool data). Ketiga metode ini akan digunakan untuk mencari metode yang paling sesuai bagi pengujian hipotesis.

Model data panel yang akan digunakan adalah sebagai berikut:

$$
\begin{aligned}
& \mathrm{LAFEE}=B_{0}+B_{1} \mathrm{AC}_{\mathrm{A}} \mathrm{MEET}_{\mathrm{it}}+B_{2} \mathrm{INS} \mathrm{OWN}_{\mathrm{it}}+ \\
& B_{3} \mathrm{D}_{-} \mathrm{INST}_{\mathrm{it}}+B_{4} \mathrm{SUB}_{\mathrm{it}}+B_{5} \mathrm{FOREIGN}_{\mathrm{it}} \\
& +B_{6} \mathrm{OPINION}_{\mathrm{it}}+B_{7} \mathrm{LEV}_{\mathrm{it}}+\mathrm{B}_{8} \mathrm{LOSS}_{\mathrm{it}} \\
& +B_{9} Q_{U A L I T Y}+\varepsilon_{i t}
\end{aligned}
$$


Untuk menentukan model regresi yang terbaik antara model Pooled Least Square (CEM) dan Fixed Effect (FEM) digunakan Chow test (Widarjono, 2007).

Rumus untuk menghitung $\mathrm{F}$ statistik adalah sebagai berikut:

$$
F=\frac{\frac{(\text { Sum squared PLS-Sum squared FEM })}{(N-1)}}{\frac{\text { Sum squared FEM }}{(N T-K)}}
$$

dimana:

$\mathrm{N}=$ jumlah data cross section

$\mathrm{T}=$ jumlah data time series

$\mathrm{K}=$ jumlah variabel penjelas

Apabila hasil F (Fstat) lebih kecil dari $\mathrm{F}_{\text {tabel, }}$ maka $\mathrm{H}_{0}$ diterima dan model yang digunakan adalah Pooled Least Square atau Common Effect Model. Apabila hasil F (Fstat) lebih besar dari

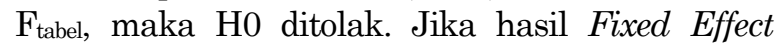
Model diterima maka dilanjutkan dengan Hausmann Test untuk mengetahui model mana yang lebih baik digunakan antara Fixed Effect Model dan Random Effect Model. Penilaian dilakukan dengan menggunakan Chi Square Statistics dan pengambilan keputusan ditentukan secara statistik.

Hipotesis:

$\mathrm{H} 0=$ Random Effect (Hausman Test $>0,05)$ atau H1 = Fixed Effect $($ Hausman Test $<0,05)$

Apabila Hausmann Test lebih besar dari 0,05 maka H0 diterima dan model yang digunakan adalah Random Effect Model. Sedangkan, apabila Hausmann Test lebih kecil dari 0,05 maka H0 ditolak dan model yang digunakan adalah Fixed Effect Model.

Sedangkan, untuk memilih model yang terbaik antara Common Effect Model dan Random Effect Model menggunakan uji Lagrage Multiplier (LM test).

Nilai LM $_{\text {hitung }}$ akan dibandingkan dengan nilai Chi Squared tabel dengan df sebanyak 12 dan $a=5 \%$. Rumusan hipotesis sebagai berikut:

H0 = Pooled Least Square $\left(\mathrm{LM}_{\text {hitung }}<\right.$ Chi Squared table) atau $\mathrm{H} 1=$ Random Effect (LM $\mathrm{LM}_{\text {hitung }}>$ Chi Squared table)

Apabila hasilnya model terbaik adalah Pooled Least Square maka perlu dilakukan pengujian asumsi regresi klasik antara lain uji multikolinearitas, autokorelasi, dan heteroskedastisitas. Hal ini dikarenakan model Pooled Least Square menggunakan pendekatan Ordinary Least Square (OLS). Sedangkan, apabila model yang terbaik adalah Random Effect maka tidak memerlukan pengujian asumsi regresi klasik (Gujarati \& Porter, 2009). Berdasarkan penjelasan tersebut maka pengujian untuk memilih model terbaik dapat digambarkan seperti Gambar 1.

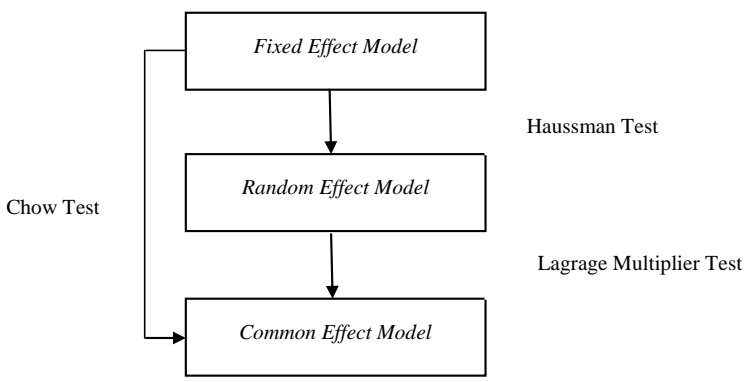

Gambar 1. Pengujian Statistik Pemilihan Model

Nilai LM $_{\text {hitung akan dibandingkan dengan }}$ nilai Chi Squared tabel dengan derajat kebebasan (degree of freedom) sebanyak jumlah variabel independent (bebas) dan alpha atau tingkat signifikansi sebesar 5\% (ditentukan di awal). Apabila nilai LM > Chi Squared tabel maka model yang dipilih adalah RE, dan sebaliknya apabila nilai LM Chi Squared tabel maka model yang dipilih adalah CEM.

1. Uji-F

Dengan menetapkan tingkat signifikansi $(\alpha=5 \%)$, maka dasar pengambilan keputusannya adalah:

a. Jika sig-F < 0.05, maka model regresi signifikan sehingga model tersebut dapat menggambarkan hubungan yang akan diteliti maka $\mathrm{HO}$ ditolak.

b. Jika sig-F $\geq 0.05$, maka model regresi tidak signifikan sehingga model tersebut tidak sesuai maka Ho tidak ditolak.

2. Uji t

Ghozali (2011) menyatakan bahwa uji statistik $\mathrm{t}$ digunakan untuk menujukkan seberapa jauh pengaruh satu variabel bebas (independen) secara individual dalam menerangkan variasi variabel terikat (dependen). Keputusan dapat dibuat dengan membandingkan nilai $p$-value dibandingkan dengan 0.05 sehingga:

a. Jika sig- $\mathrm{t}<0.05$, koefisien regresi signifikan maka $\mathrm{H} 0$ ditolak

b. Jika sig-t $\geq 0.05$, koefisien regresi tidak signifikan maka $\mathrm{H} 0$ tidak ditolak.

3. Uji Koefisien Determinasi $\left(\mathrm{R}^{2}\right)$

Goodness of fit (uji koefisien determinasi) bertujuan untuk mengukur tingkat variasi nilai variabel dependen yang dapat dijelaskan oleh variabel-variabel independen (Ghozali, 2011). Pengujian ini perlu dilakukan untuk dapat mengetahui seberapa baiknya model penelitian 
yang digunakan. Baik tidaknya suatu model dalam penelitian dengan regresi linear dapat dilihat dari nilai adjusted $\mathrm{R}^{2}$, dengan rentang nilai 0 (nol) sampai dengan 1 (satu). Semakin tinggi nilai koefisien determinasi, maka semakin baik model dalam menjelaskan hubungan antara variabel independen dan variabel dependen.

\section{HASIL PENELITIAN DAN PEMBAHASAN}

\section{Analisis Statistika Deskriptif}

Data yang diperoleh pada tahun 2010 sebanyak 248 perusahaan, tahun 2011 sebanyak 281 perusahaan, tahun 2012 sebanyak 260 perusahaan dan tahun 2013 sebanyak 332 perusahaan. Pada penelitian ini, pengolahan data dilakukan dengan bantuan Eviews data panel sehingga data yang diolah harus lengkap selama periode amatan yaitu 4 tahun berturut-turut. Setelah diseleksi, tersisa hanya 31 perusahaan yang memiliki data lengkap selama 4 tahun, sehingga total observasi sebanyak 124. Hasil dari uji statistik deskriptif dapat terlihat pada Tabel 1.

Tabel 1. Hasil Uji Statistik Deskriptif

\begin{tabular}{lcrrr}
\multicolumn{5}{c}{ Descriptive Statistics } \\
\hline N & Minimum & Maximum & \multicolumn{1}{c}{ Mean } \\
\hline Auditfee & 124 & 18.76 & 27.89 & 21.6035 \\
ac_meet & 124 & 1 & 41 & 7.21 \\
ins_own & 124 & .00 & 78.55 & 3.4532 \\
sub & 124 & 0 & 78 & 7.19 \\
lev & 124 & .010 & 8.410 & .22323 \\
Valid N (listwise) & 124 & & & \\
\hline
\end{tabular}

Berdasarkan Tabel 1 dapat diperoleh nilai biaya audit (LN_AUDITFEE) max (min) adalah 27.89 atau $\mathrm{Rp} 887.449 .000,-$ (18.76 atau 170.125.000.-) dengan mean 21.6035 atau $\mathrm{Rp}$ 270.000.000,-. Hal ini berarti rata-rata perusahaan sampel memiliki biaya audit yang cukup tinggi. Pada variabel pertemuan komite audit (AC_MEET) menunjukkan jumlah max (min) adalah 41 kali (1 kali) dengan mean 7.2 kali pertemuan dalam setahun. Hal ini berarti komite audit perusahaan sampel melaksanakan pertemuan rata-rata 7 kali dalam setahun, jumlah pertemuan ini telah melebihi jumlah minimal yang disyaratkan oleh BAPEPAM, yaitu 4 kali dalam setahun. Hal ini menunjukkan bahwa perusahaan sampel telah berusaha melakukan pengawasan yang lebih tinggi dengan adanya jumlah pertemuan komite audit yang tinggi untuk meyakinkan akan kualitas laporan keuangan yang dihasilkan oleh manajemen perusahaan. Variabel kepemilikan institusional menunjukkan jumlah max (min) adalah 78.55\% (0\%) dengan mean 3.45\% hal ini menunjukkan, rata-rata perusahaan sampel memiliki proporsi kepemilikan institusional yang cukup rendah, karena kepemilikannya tidak ditujukan untuk memiliki kendali atan hak suara yang tinggi di perusahaan emiten.

Pada variabel kontrol jumlah perusahaan anak yang dimiliki (SUB) menunjukkan jumlah max (min) adalah 78 anak perusahaan (0 anak perusahaan) dengan mean 7.19, hal ini menunjukkan bahwa rata-rata perusahaan sampel memiliki cukup banyak anak perusahaan sehingga akan menambah tingkat kompleksitas proses pelaporan keuangan dan proses audit. Pada variabel tingkat ungkitan (LEV) yang dimiliki perusahaan sampel menunjukkan jumlah max (min) adalah 8.41 (0.010) dengan mean 0.223 menunjukkan tingkat ungkitan (leverage) yang dimiliki perusahaan sampel sangat kecil, tidak sampai 1. Nilai mean lev 0.223 berarti setiap 100 asetnya dibiayai dengan hutang sebesar 0.2 .

Tabel 2. Hasil Uji Statistik Deskriptif-Frekuensi

\begin{tabular}{crrrrcrrrrr}
\hline Dummy D_Inst & $\%$ & Foreign & $\%$ & Opinion & $\%$ & Loss & $\%$ & Quality & $\%$ \\
\hline 0 & 118 & 95.2 & 83 & 66.9 & 120 & 96.8 & 109 & 87.9 & 68 & 54.8 \\
1 & 6 & 4.8 & 41 & 33.1 & 4 & 3.2 & 15 & 12.1 & 56 & 45.2 \\
\hline
\end{tabular}

Pada variabel kepemilikan institusional diffused dan blockholder yang diukur dalam dummy, menunjukkan bahwa sebagian besar perusahaan sample memiliki kepemilikan diffused (95.2\%) dan hanya sebagian kecil yang memiliki saham secara blockholder (4.8\%). Variabel control kepemilikan anak perusahaan di luar negeri (FOREIGN), menunjukkan sebagian besar (66.9\%) perusahaan sampel pada dummy nilai 0 yang berarti tidak memiliki anak perusahaan di luar negeri, hanya sebagaian kecil (33.1\%) yang memiliki anak perusahaan di luar negeri. Variabel kontrol opini yang diberikan auditor kepada perusahaan emiten menunjukkan bahwa sebagian besar perusahaan sampel (96.8\%) menerima opini modified opinion sedangkan hanya $3.2 \%$ dari perusahaan sampel mendapatkan opini unmodified opinion. Variabel control perusahaan yang menderita rugi (LOSS) menunjukkan bahwa sebagian besar perusahaan sampel (87.9\%) masih melaporkan laba di tahun amatan sedangkan hanya $12.1 \%$ dari perusahaan sampel melaporkan rugi. Pada variabel control penggunaan audit berkualitas dari perusahaan Big four (QUALITY) menunjukkan bahwa sebagian perusahaan sampel (54.8\%) masih menggunakan KAP non-big four sedangkan $45.2 \%$ dari perusahaan sampel menggunakan auditor big four. 


\section{Analisis Regresi Data Panel}

\section{Pemilihan Model Terbaik}

1. Common Effect Model (The Pooled OLS Method $=P L S)$

Common ini sama dengan metode OLS (Regresi Biasa) dimana intersep dan slopenya tetap antar waktu dan individu. Hasil dari model common effect terlihat pada Tabel 3.

Tabel 3. Hasil Pengujian Common Effect Model (CEM)

\begin{tabular}{crrrr}
\hline Variable & Coefficient & Std. Error & t-Statistic & Prob. \\
\hline AC_MEET & 0.044422 & 0.015133 & 2.935405 & 0.0040 \\
INS_OWN & -0.000735 & 0.018233 & -0.040331 & 0.9679 \\
D_INST & -0.343678 & 0.836227 & -0.410987 & 0.6819 \\
_SUB & 0.045921 & 0.008078 & 5.684683 & 0.0000 \\
FOREIGN & 0.563325 & 0.235230 & 2.394783 & $0.0183^{*}$ \\
OPINION & -0.094230 & 0.653402 & -0.144215 & 0.8856 \\
LEV & 0.090981 & 0.139613 & 0.651662 & 0.5159 \\
LOSS & -0.610545 & 0.351001 & -1.739441 & $0.0847^{*}$ \\
QUALITY & 1.437089 & 0.240928 & 5.964816 & 0.0000 \\
C & 20.19381 & 0.197808 & 102.0882 & 0.0000 \\
\hline R-squared & 0.557598 & Mean dependent var & 21.60355 \\
Adjusted R-squared & 0.522671 & S.D. dependent var & 1.696765 \\
S.E. of regression & 1.172278 & Akaike info criterion & 3.232981 \\
Sum squared resid & 156.6627 & Schwarz criterion & 3.460423 \\
Log likelihood & -190.4448 & Hannan-Quinn criter. & 3.325374 \\
F-statistic & 15.96490 & Durbin-Watson stat & 0.591867 \\
Prob(F-statistic) & 0.000000 & & \\
*) signifikan pada level a = 10\% & & & \\
*) & & &
\end{tabular}

\section{Fixed Effect Model (FEM)}

Pada Fixed Effect Model muncul masalah 'near singular matrix", hal ini disebabkan oleh dalam data penelitian yang telah diperoleh, terdapat beberapa perusahaan yang memiliki data sama selama periode amatan seperti data opini, kualitas auditor, kepemilikan institusional yang menggunakan dummy. Hal ini menyebabkan pengujian dengan FEM tidak dapat dilanjutkan.

3. Random Effect Model (REM)

Pengujian dilanjutkan dengan model Random Effect Model (REM) yang disajikan pada Tabel 4.

Tabel 4. Hasil Pengujian Random Effect Model (REM)

\begin{tabular}{crrrr}
\hline Variable & Coefficient Std. Error & t-Statistic & \multicolumn{1}{c}{ Prob. } \\
\hline AC_MEET & 0.026919 & 0.016816 & 1.600760 & $0.0922^{*}$ \\
INS_OWN & 0.011499 & 0.013862 & 0.829527 & 0.4085 \\
D_INST & -0.508380 & 0.660444 & -0.769755 & 0.4430 \\
SUB & 0.053588 & 0.013877 & 3.861737 & 0.0002 \\
FOREIGN & 0.997044 & 0.282891 & 3.524477 & 0.0006 \\
OPINION & -0.333606 & 0.556606 & -0.599357 & 0.5501 \\
LEV & 0.052051 & 0.099771 & 0.521709 & 0.6029 \\
LOSS & -0.333427 & 0.284154 & -1.173402 & 0.2431 \\
QUALITY & 1.352424 & 0.416775 & 3.244972 & 0.0015 \\
C & 20.10834 & 0.298190 & 67.43455 & 0.0000 \\
\hline \multicolumn{5}{c}{ Weighted Statistics } \\
\hline R-squared & 0.346060 & Mean dependent var & 7.310263 \\
Adjusted R-squared & 0.294433 & S.D. dependent var & 0.872014 \\
S.E. of regression & 0.732475 & Sum squared resid & 61.16322 \\
F-statistic & 6.703095 & Durbin-Watson stat & 1.416031 \\
Prob(F-statistic) & 0.000000 & & \\
\hline \multicolumn{5}{c}{ Unweighted Statistics } \\
R-squared & 0.526819 & Mean dependent var & 21.60355 \\
Sum squared resid & 167.5621 & Durbin-Watson stat & 0.516877 \\
\hline
\end{tabular}

Setelah pengujian dengan ketiga model estimasi, peneliti akan memilih model yang paling baik untuk digunakan dalam analisis. Oleh karena FEM tidak dapat digunakan dalam penelitian ini maka peneliti hanya perlu memilih dari antara dua model, yaitu antara CEM dan REM. Pemilihan metode dilakukan dengan pengujian Lagrange Multiplier (LM) Test. Dari hasil pengujian LM, diperoleh nilai LM hitung sebesar 3271.84, dimana nilai itu lebih besar dari tabel Chi-Square $(\mathrm{df}=9)$ sebesar 16.91898. Hal ini berarti menolak Ho, yaitu estimasi yang tepat untuk model regresi data panel adalah Random Effect Model (REM). Dengan demikian, hasil pengujian dari model random effect yang akan digunakan untuk analisis selanjutnya yakni uji $\mathrm{F}$, uji t, dan uji koefisien determinasi.

\section{Uji F}

Berdasarkan hasil pengujian pada Tabel 4 menunjukkan bahwa nilai signifikansi $\mathrm{F}$ sebesar 0.000000 artinya model regresi cukup baik untuk digunakan dalam pengujian. Oleh karena itu, variabel independen secara bersama-sama mampu menjelaskan variabel dependen.

\section{Uji $t$}

Hasil pengujian yang tersaji pada Tabel 4 menunjukkan bahwa pada hipotesis pertama dinyatakan bahwa terdapat pengaruh jumlah pertemuan komite audit (AC_MEET) terhadap biaya audit. Dari hasil pengujian diperoleh hasil signifikansi sebesar 0.0922 dengan koefisien sebesar 0.026919. Hasil signifikansi tersebut lebih kecil daripada tingkat $a=10 \%$ dengan nilai koefisien memiliki arah positif yang berarti sesuai dengan yang telah dihipotesiskan. Hal ini artinya H1 diterima. Hasil ini tidak mendukung hasil penelitian Lin et al (2006). Pada hipotesis kedua dinyatakan bahwa terdapat pengaruh kepemilikan institusional (INS_OWN) terhadap biaya audit. Dari hasil pengujian diperoleh hasil signifikansi sebesar 0.4085 dan koefisien regresi sebesar 0.011499. Hasil signifikansi tersebut lebih besar dari tingkat a yang ditetapkan sehingga H2 ditolak. Pada hipotesis ketiga dinyatakan bahwa terdapat perbedaan pengaruh kepemilikan institusional diffused dan blockholders (D_INST) terhadap biaya audit. Dari hasil pengujian diperoleh hasil signifikansi sebesar 0.4430 . Hasil signifikansi tersebut lebih besar dari tingkat a yang ditetapkan sehingga H3 ditolak.

Hasil pengujian untuk variabel kontrol menunjukkan bahwa variabel untuk anak perusahaan (SUB) memiliki nilai signifikansi 0.0002 (lebih kecil dari $\alpha=5 \%$ ) yang berarti terdapat pengaruh 
variabel SUB terhadap biaya audit yaitu semakin tinggi jumlah anak perusahaan yang dimiliki maka semakin tinggi pula biaya auditnya. Pada variabel FOREIGN terhadap biaya audit yaitu pada perusahaan yang memiliki anak perusahaan di luar negeri, memiliki nilai signifikansi 0.0006 (lebih kecil dari $\alpha=5 \%$ ) yang berarti terdapat pengaruh variabel FOREIGN terhadap biaya audit yaitu biaya auditnya terpengaruh dari jumlah anak perusahan di luar negeri. Hasil ini sesuai dengan hasil penelitian Adelopo et al. (2012). Variabel "Sub" dan "Foreign" merupakan proxy dari auditee complexity dapat timbul karena inherent risk (yaitu resiko bisnis klien) atau timbul karena transaksi yang complex. Bila perusahaan memiliki transaksi yang complex maka akan memerlukan waktu audit lebih lama dan memerlukan auditor yang berpengalaman, untuk mengurangi risk of material misstatement ke level yang dapat diterima sehingga akan mengurangi audit risk. Pada variabel kualitas audit (QUALITY) memiliki nilai signifikansi 0.0015 (lebih kecil dari $\alpha=5 \%$ ) yang berarti terdapat pengaruh variabel QUALITY terhadap biaya audit yang mana perusahaan yang menggunakan jasa dari KAP big four maka biaya auditnya lebih tinggi dibandingkan dengan perusahaan yang menggunakan jasa dari KAP non-big four. Tingginya biaya audit dari KAP big four karena KAP tersebut diidentikan dengan jasa audit berkualitas tinggi yang disebabkan KAP tersebut memiliki banyak sumber daya yang lebih tinggi sehingga lebih mampu menemukan adanya salah saji yang material sehingga lebih memberikan jaminan reliabilitas laporan keuangan auditan.

Namun beberapa variabel control seperti, variabel OPINI memiliki nilai signifikansi 0.5501 (lebih besar dari a yang ditetapkan) yang berarti tidak terdapat pengaruh variabel OPINI terhadap biaya audit. Leverage (LEV) yang merupakan variable control dari financial risk, memiliki nilai signifikansi 0.6029 (lebih besar dari a yang ditetapkan) yang berarti tidak terdapat pengaruh variabel leverage terhadap biaya audit. Pada variabel perusahaan yang mengalami kerugian pada periode amatan (LOSS), sebagai proxy pengukuran profitabilitas, memiliki nilai signifikansi 0.2431 (lebih besar dari a yang ditetapkan) yang berarti tidak terdapat pengaruh variabel LOSS terhadap biaya audit. Hasil ini konsisten dengan penelitian Fields et al. (2004) dan Mitra et al. (2007). Tidak signifikannya antara Loss dan biaya audit mungkin dapat disebabkan karena sulitnya merumuskan (menentukan) proxy yang tepat untuk profitabilitas terutama karena dipengaruhi oleh berbagai manipulasi akuntansi.

\section{Uji Koefisien Determinasi}

Berdasarkan Tabel 3 menunjukkan bahwa nilai koefisien determinasi $\mathrm{R}^{2}$ sebesar 0.346060 , hal ini dapat diartikan bahwa sekitar 34.60\% perubahan audit fee dipengaruhi oleh variabelvariabel penentu dalam model ini sedangkan sisanya $65.40 \%$ dijelaskan oleh variabel lain yang tidak dimasukkan dalam model ini.

\section{Aktivitas Komite Audit dan Biaya Audit}

Pada hipotesis pertama dinyatakan bahwa terdapat pengaruh jumlah pertemuan komite audit terhadap biaya audit. Hasil pengujian menunjukkan hasil p-val dibawah $10 \%$ dan koefisien regresi yang positif sehingga menunjukkan bahwa jumlah pertemuan komite audit berpengaruh positif terhadap biaya audit. Dari hasil pengujian diperoleh hasil bahwa hipotesis tersebut diterima, namun hasil penelitian ini tidak sesuai dengan penelitian Adelopo (2012). Dan bila kita melihat dari hasil statistik deskriptif menunjukkan ratarata jumlah pertemuan komite audit diatas yang disyaratkan BAPEPAM dan rata-rata biaya audit yang tinggi (table 4.1).

Hasil penelitian ini mendukung pernyataan Beasley et al. (2000) dan Abbott et al. (2000). Beasley et al. (2000) menyebutkan bahwa pada perusahaan yang melakukan kecurangan, ditemukan disebabkan karena komite audit bertemu kurang sering bila dibandingkan daripada komite audit dari perusahaan yang non-fraud (tidak melakukan kecurangan). Perusahaan yang diketahui melakukan kecurangan akan meningkatkan biaya audit. Hasil penelitian ini juga mendukung penelitian Carcello et al. (2002) yang memperoleh hasil adanya pengaruh positif jumlah rapat komite audit terhadap biaya audit. Hal ini terjadi karena komite audit berkepentingan untuk memberikan sinyal efisiensi, menjaga reputasi, dan menghindari resiko litigasi, dengan konsekuensi akan meningkatkan lingkup audit sehingga juga akan meningkatkan biaya audit

\section{Kepemilikan Institusional dan Biaya Audit}

Pada hipotesis kedua dinyatakan bahwa terdapat pengaruh kepemilikan institusional terhadap biaya audit. Dari hasil pengujian diperoleh hasil bahwa hipotesis tersebut ditolak. Demikian juga dengan hipotesis ketiga yang ditolak, artinya tidak ada perbedaan antara kepemilikan institusional diffused dan blockholders. Hal ini dapat disebabkan karena keputusan untuk melakukan audit berkualitas tinggi tidak bergantung hanya pada besarnya kepemilikan institusional, namun 
tergantung seberapa besar keinginan manajemen untuk mendapatkan kepercayaan investor akan informasi yang terkandung dalam laporan keuangan. Hal ini juga dapat terlihat dari bukti dari data yang telah diperoleh, bahwa kepemilikan institusional pada perusahaan sampel hanya rendah namun biaya audit perusahaan sampel adalah tinggi (Tabel 1).

Data dari perusahaan sampel juga menunjukkan bahwa kepemilikan institusional sebagian besar di bawah 20\% yang artinya lebih banyak yang kepemilikan diffused. Pada tingkat kepemilikan diffused (<20\%), para investor institusional cenderung kurang ada keinginan dan kemampuan untuk memonitor aktivitas perusahaan dibandingkan apabila investor institusional blockholder (>20\%) sehingga investor institusional diffused kurang dapat memaksa perusahaan melakukan audit berkualitas tinggi untuk menghindari kecurangan dalam pelaporan keuangan. Hasil penelitian ini tidak sesuai dengan hasil penelitian Mitra et al. (2007) bahwa terdapat hubungan negatif antara kepemilikan institusional blockholder dengan biaya audit.

\section{KESIMPULAN DAN SARAN}

Penelitian ini memiliki tujuan untuk memberikan bukti empiris pengaruh karakteristik komite audit dan kepemilikan saham terhadap audit fee. Sampel penelitian adalah perusahaanperusahaan yang terdaftar di BEI selama periode pengamatan 2010-2013. Analisis data yang digunakan yaitu analisis regresi panel dengan jumlah observasi sebanyak 124 .

Hasil penelitian menunjukkan bahwa model yang terbaik untuk menjelaskan pengaruh variabel independen terhadap biaya audit adalah random effect yang membuktikan aktivitas komite audit yang diukur oleh jumlah pertemuan komite audit memiliki pengaruh yang positif terhadap biaya audit. Sedangkan, kepemilikan saham institusional tidak terbukti mempengaruhi biaya audit. Demikian juga tidak terdapat perbedaan pengaruh yang signifikan antara kepemilikan institusional diffused dan blockholders terhadap biaya audit. Hasil untuk variabel kontrol membuktikan bahwa jumlah anak perusahaan yang dimiliki (SUB), adanya anak perusahaan di luar negeri (FOREIGN), dan kualitas audit (QUALITY) berpengaruh secara signifikan terhadap biaya audit. Sedangkan, variabel kontrol lain yakni leverage, loss dan opini audit tidak berpengaruh secara signifikan terhadap biaya audit.

Keterbatasan dalam penelitian ini adalah pertama, jumlah sampel yang diperoleh dalam penelitian ini cukup kecil, hal ini disebabkan karena terbatasnya jumlah perusahaan yang memiliki data yang lengkap sesuai yang diperlukan dalam penelitian ini, kedua, pada penelitian ini model fixed effect tidak terbentuk karena adanya variabel kontrol yang datanya sama setiap tahunnya yaitu opini, kualitas audit, foreign dan loss, ketiga, tiak tersedianya data 'biaya audit' di laporan keuangan sehingga peneliti menggunakan data 'profesional fee' untuk digunakan sebagai data biaya audit. Penelitian ini masih terbuka untuk penelitian lain di bidang yang sama, karena nilai R2 masih bernilai 34,60\% yang berarti masih banyak variabel lain yang belum masuk dalam model penelitian ini. Untuk penelitian selanjutnya, peneliti menyarankan untuk memasukkan variabel GCG lain seperti; karaktersitik komite audit yang diukur dari independensi komite audit, keahlian komite audit, dan aktivitas komite audit; karakteristik dewan komisaris dan karakteristik kepemilikan saham. Selain itu, peneliti juga menyarankan untuk memasukkan sektor industry lain dalam sampel penelitian seperti sektor jasa, dagang dan lain-lain.

\section{DAFTAR PUSTAKA}

Abbott, L. J. and Parker, S. (2000). Auditor selection and audit committee characteristics. Auditing: A Journal of Practice \& Theory, 19(2), 47-66.

Abbott, L. J., Park, Y., and Parker, S. (2000). The effects of audit committee activity and independence on corporate fraud. Managerial Finance, 26(11), 55-67.

Abbott, L., Parker, S., Peters, G., and Raghunandan, K. (2003a). The Association between audit committee characteristics and audit fees. Auditing: A Journal of Practice and Theory, 22, 17-32

Abbott, L., Parker, S., Peters, G., and Raghunandan, K. (2003b). An Empirical investigation of Audit Fees, Non-Audit Fees, and Audit Committee. Contemporary Accounting Research, 20, 215-234

Ismail, A., Kumba, J., and Peter. S. (2012). Multiple large ownership structure, audit committee activity and audit fees. Journal applied Accounting Research, 13(2), 100-121

Barkess, L. and Simnett, R. (1994). The Provision of Other Services by Auditors: Independence and pricing issues. Accounting and Business Research, 24(94), 99-108.

Beasley, M. S., Carcello, J. V., Hermanson, D.R., and Lapides, P.D. (2000). Fraudulent Financial Reporting: Consideration of Industry Traits and Corporate Governance Mechanisms. Accounting Horizons, 14(4), 441-454. 
Becker, C. L., Defond, M., Jiambalvo, J., and Subramanyam, K. R. (1998). The Effect of Audit Quality on Earnings Management. Contemporary Accounting Research, 15, 1-24.

Carcello, J., Hermanson, D., Neal, T. L., Riley, R. A. (2002). Board Characteristics and Audit Fees, Contemporary Accounting Research, 19, 365-384.

DeZoort, F. T. (1997). An Investigation of Audit Committees' Oversight Responsibilities. Abacus (September), 208-227.

Emby, C. and Davidson, R. (1998). The Effects of Engagement Factors on Auditor Independence: Canadian Evidence. Journal of International Accounting, Auditing and Taxation, 7(Spring), 163-179.

Fields, L. P., Fraser, D. R. and Wilkins, M. S. (2004). An Investigation of The Pricing of Audit Services For Financial Institutions. Journal of Accounting and Public Policy, 23(23), 53-77.

Ferdinand, G. A., and Judy, T. S. L. (1998). A Test of The Free Cash Flow and Debt Monitoring Hypothesis: Evidence From Auditing Pricing. Journal of Accounting and Economics, 24, 219-237.

Ferdinand, G. A., and Judy, T. S. L. (2001). Free Cash Flow, Debt Monitoring, and Audit Pricing: Further Evidence on the role of Director Equity Ownership. Auditing: A Journal of Practice \& Theory, 20,71-84.

Ghozali, I. (2011). Aplikasi Analisis Multivariate dengan Program IBM SPSS 19. $5^{\text {th }}$ edition. Semarang: Badan Penerbit Universitas Diponegoro.

Gujarati, D. N. and Porter, D. C. (2009). Basic Econometrics, $5^{\text {th }}$ edition, McGraw-Hill.

Jensen, M. C. and Meckling, W. H. (1976). Theory of the Firm: Manajerial Behavior, Agency Cost and Ownership Structure. Journal of Financial and Economics, 3, 305-360.

Kane, G. D. and Velury, U. (2004). The Role of Institutional Ownership In The Market For Auditing Services: An Empirical Investigation. Journal of Business Research, 57(9), 976983.

Kirk, P. (1994). Strengthening The Professionalism of The Independent Auditor. Stamford, CT: Public Oversight Board.

Knapp, M. (1985). Audit Conflict: An Empirical Study of the Perceived Ability of Auditors to
Resist Management Pressure. The Accounting Review, 60, 202-211.

Lin, J.W. (2006). The Effect of Audit Committee Performance on Earnings Quality. Managerial Auditing Journal 21(9), 921-933.

Peraturan_Bapepam/IX.I.5_Pembentukan_dan_Pe doman_Pelaksanaan_Kerja_Komite_Audit.pd f http://www.martinaberto.co.id/download/

Menon, K. and Williams, J. D. (1994). The Use of Audit Committees For Monitoring. Journal of Accounting and Public Policies, 13(2), 121-139.

Monks, R. A. G. and Minow (2011). Corporate Governance, $4^{\text {th }}$ edition, Blackwell Publishing

Mitra, S., Hossain, M., and Deis. D. R. (2007). The Empirical Relationship Between Ownership Characteristics And Audit Fees. Rev Quant Finan Acc, 28,257-285

Palmrose, Z. V. (1986). The Effect of Nonaudit Services on The Pricing of The Audit Services: Furter evidence. Journal of Accounting Research, 24, 405-421.

Raghunandan, K., Read, W. J., ans Rama, D. V. (2001). Audit Committee Composition, "Gray Directors," And Interaction with Internal Auditing. Accounting Horizons (June), 105118.

Scott, W. R. (1997). Financial Accounting Theory. New Jersey: Prentice-Hall, Inc.

Sharma, V., Vic, N., and Barry, L. (2009). Determinants of Audit Committee meeting Frequency: Evidence from a Voluntary Governance System. Accounting Horrizons, 23 (3), 245-263.

Simunic, D. A. and Stein, M. T. (1996). The impact of litigation risk on audit pricing: A review of the economics and the evidence. Auditing: $A$ Journal of Practice \& Theory, 15 (Supplement), 119-134.

Spira, L. (1999). Independence in Corporate Governance: The Audit Committee Role. Business Ethics: A European Review, 8(4), 262-273.

Tsui, J., Jaggi, B., and Gul, F. (2001). CEO Domination, Discretionary Accruals and Audit Fees. Journal of Accounting, Auditing and Finance (Summer), 189-207.

Verschoor, C. C. (1993). Benchmarking the Audit Committee. Journal of Accountancy, 176, 59-64.

Watts, R. and Zimmerman, J.L. (1986). Positive Accounting Theory. New York: Prentice-Hall.

Widarjono, A. (2009). Ekonometrika Pengantar dan Aplikasinya. Edisi 3. Ekonosia: Fakultas Ekonomi UII. 